\title{
BRAIN CONNECTIVITY CHANGES IN PATIENTS WITH WORKING MEMORY IMPAIRMENTS WITH CHRONIC ISCHEMIC CEREBROVASCULAR DISEASE
}

Fokin VF $₫$, Ponomareva NV, Konovalov RN, Krotenkova MV, Medvedev RB, Lagoda OV, Tanashyan MM

Research Center of Neurology, Moscow, Russia

One of the methods of assessment of cognitive functions in patients with chronic ischemic cerebrovascular disease — CICD (dyscirculatory encephalopathy) implies studying connectivity of neural networks through the analysis of rest functional magnetic resonance imaging (rest fMRI) data. The main objective of this study was to assess the relationship between working memory (WM) characteristics and connectivity of various parts of the brain in patients diagnosed with CICD. The study involved 22 female CICD patients; they were divided into two groups, one with satisfactory level of WM and the other with compromised WM. We assessed intra-brain connectivity with the help of rest fMRI, using the SPM-12 and CONN18b software applications in Matlab platform. The other aspects evaluated were the gray to white matter ratio and the association of this indicator with WM. Significant differences in the intra-brain connectivity were registered in both the satisfactory WM group and the compromised WM group. The brain parts where those differences were found are left parahippocampal area and right supramarginal gyrus; right cerebellar hemisphere and left parietal, as well as left frontal areas; right cingular and left lingual gyri. In addition, we detected significant differences in the ratio in the gray and white matter volumes in both groups $(p=0.007)$. The results obtained indicate that memory deterioration in CICD patients is concomitant with deteriorating connectivity between the cortical areas, as well as between cerebellum and cortex, which may be associated with a more significant loss of the white matter.

Keywords: neuroimaging, rest fMRI, working memory, connectivity, cognitive functions, gray and white matter of the brain, chronic ischemic cerebrovascular disease Funding: the study was ordered by the Research Center of Neurology (Federal Research Institution).

Author contribution: Fokin VF — data analysis, article authoring; Ponomareva NV — psychometric and neuroimaging data collection and analysis, participation in authoring the article; Konovalov RN — neuroimaging, processing of the results; Krotenkova MV — neuroimaging, analysis of the results; Medvedev RB - clinical examinations, analysis of the literature; Lagoda OV — analysis of the clinical data; Tanashyan MM — generalization of the clinical material in the context of the results obtained.

Compliance with ethical standards: the study was approved by the Research Center of Neurology Ethics Committee (Protocol № 11/14 dated November 19, 2014); all participants signed the voluntary informed consent.

$\triangle$ Correspondence should be addressed: Vitaly F. Fokin

Volokolamskoye shosse, 80, Moscow, 125367; fvf@mail.ru

Received: 19.08.2019 Accepted: 13.09.2019 Published online: 22.09.2019

DOI: $10.24075 /$ brsmu.2019.061

\section{ИЗМЕНЕНИЯ КОННЕКТИВНОСТИ ГОЛОВНОГО МОЗГА У БОЛЬНЫХ С НАРУШЕНИЯМИ ВЕРБАЛЬНОЙ ОПЕРАТИВНОЙ ПАМЯТИ ПРИ ДИСЦИРКУЛЯТОРНОЙ ЭНЦЕФАЛОПАТИИ}

В. Ф. Фокин 凶, Н. В. Пономарева, Р. Н. Коновалов, М. В. Кротенкова, Р. Б. Медведев, О. В. Лагода, М. М. Танашян

Научный центр неврологии, Москва, Россия

Один из методов оценки когнитивных функций у пациентов с хроническими цереброваскулярными заболеваниями - исследование коннективности нейросетей с помощью анализа показателей функциональной магнитно-резонансной томографии (фМРТ) покоя. Основной целью исследования было оценить взаимосвязь коннективности различных отделов мозга с характеристиками вербальной оперативной памяти (ВОП) у больных с дисциркуляторной энцефалопатией (ДЭ). В исследовании участвовали 22 женщины с ДЭ, разделенные на две группы: с удовлетворительной и сниженной ВОП. У всех пациенток определяли коннективность между различными областями мозга с помощью анализа фМРТ покоя с использованием программных приложений SPM-12 и CONN18b в среде Matlab, а также оценивали отношение объемов серого вещества к белому и сопряженность этого показателя с ВОП. У больных в группе с удовлетворительной ВОП и в группе со сниженной ВОП статистически значимые различия коннективности обнаружены между следующими областями: левой парагиппокампальной областью и правой супрамаргинальной извилиной; правым полушарием мозжечка и левой теменной, а также левой лобной областями; правой поясной и левой язычной извилинами. Кроме того, в обеих группах выявлены статистически значимые различия в отношениях между объемами серого и белого вещества ( $p=0,007)$. Полученные результаты указывают, что снижение памяти у больных с ДЭ сопровождается сокращением коннективности между областями коры, а также между мозжечком и корой, что может быть связано с более значительной утратой белого вещества.

Ключевые слова: дисциркуляторная энцесалопатия, нейровизуализация, фМРТ покоя, вербальная оперативная память, коннективность, когнитивные функции, серое и белое вещество мозга

Финансирование: работа была выполнена в рамках государственного задания ФГБНУ НЦН.

Информация о вкладе авторов: В. Ф. Фокин - анализ данных, написание статьи; Н. В. Пономарева - сбор и анализ психометрических и нейровизуалиционных данных, участие в написании статьи; Р. Н. Коновалов - нейровизуалиционные исследования, обработка результатов; М. В. Кротенкова - нейровизуалиционные исследования, анализ результатов; Р. Б. Медведев - клинические обследования, анализ литературы; О. В. Лагода - анализ клинических данных; М. М. Танашян - обобщение клинического материала в контексте полученных результатов.

Соблюдение этических стандартов: исследование одобрено этическим комитетом Научного центра неврологии (протокол № 11/14 от 19 ноября 2014 г.); все участники подписали информированное согласие на участие в исследовании.

$\bowtie$ Для корреспонденции: Виталий Федорович Фокин Волоколамское ш., д. 80, г. Москва, 125367; fvf@mail.ru

Статья получена: 19.08.2019 Статья принята к печати: 13.09.2019 Опубликована онлайн: 22.09.2019

DOI: $10.24075 /$ vrgmu.2019.061 
Vascular brain damage in the elderly is an important problem from both the medical and the socio-economic viewpoints. According to a number of researchers, 5 to $22 \%$ of the senior citizens are diagnosed with cognitive impairments of vascular origin [1, 2]. In the Russian scientific literature, such disorders are traditionally considered through the lens of chronic ischemic cerebrovascular disease - CICD (dyscirculatory encephalopathy). Mnestic disorders, including working memory (WM) deterioration, occupy a certain place in the clinical picture of CICD [3-5]. From the pathomorphological point of view, CICD-conditioned cognitive impairments result from diffusive and multiple lacunar local changes in the subcortical white matter and cerebral cortex. The most common subcortical disorders are associated with atherosclerotic lesions or lipohyalinosis of the small penetrating arteries delivering blood to the deep parts of the brain [4]. Numerous studies show that from the neurochemical point of view vascular cognitive impairments result from acetylcholinergic deficiency. With CICD in the background, it is brought by the periventricular white matter ischemia, since acetylcholinergic axons pass through the white matter [6]. There is no doubt it is necessary to detect cognitive impairments at an early stage since timely therapy prescribed early yields best results and improves the prognosis. Cognitive activity runs against the background of coordinated processing of information in different areas of the brain. Neural network communication disruptions affect the contiguity of information coming from various areas of the brain, which leads to the cognitive dysfunction. Incomplete synchronization of neocortex with paleocortex and archicortex, subcortex and cerebellum is one of the reasons behind diminution of the higher mental functions, including memory. Aging is one of the factors promoting such processes, especially when there are vascular and neurodegenerative brain diseases in the background; often, they are caused by the diminishing volume of white matter that is a communication medium for the various parts of the brain $[7,8]$.

Connectivity is the term used to describe the unity of the various components of the system that makes it a single whole, and it is applicable to the brain. The data delivered by rest $\mathrm{fMRI}$ that allows evaluating connectivity is the BOLD (blood oxygen level-dependent) signal synchronization in various parts of the brain. According to the rest $\mathrm{fMRI}$ and the background electroencephalography data, connectivity is related to the cognitive functions, including memory. In general, deterioration of connectivity between different regions of the brain leads to cognitive dysfunction $[9,10]$.

Normal functioning of the nerve networks depends on the adequacy of blood supply to metabolic needs. With CICD, connectivity in the neural networks worsens, which is to be expected, as do the cognitive functions. The process is the results of death of neurons and their axons in various parts of the brain. MRI scans of the brain of elder people often exhibit damaged white matter, the lesions actively contributing to the cognitive decline and dementia pathogenesis. Vascular risk factors are connected to the white matter damage, which hinders synchronization between various parts of the brain, especially those remote to each other. In practice, the gray to white matter ratio is a common indicator allowing assessment of damage to the gray or white matter [11, 12].

This study aimed to use rest fMRI data to assess the contingency between WM and connectivity alterations, as well as the gray to white matter ratio, in CICD patients.

\section{METHODS}

The study was conducted at the Research Center of Neurology (Federal Research Institution) in 2017-2019. There were 22 patients aged $50-85$ years (mean age 64 years) participating in the study, all female. The inclusion criteria were: chronic cerebrovascular diseases $(\mathrm{CICD}$, stage 1-2, the diagnosis complying with the brain and spinal cord vascular trauma classification developed by the RAMS Research Institute of Neurology in 1985); underlying vascular disease and disseminated local neurological symptoms concomitant with cerebral symptoms: headache, dizziness, tinnitus, compromised memory, working ability and intelligence; registered arterial hypertension; cognitive impairment (impaired memory, working ability, irritability) [13]; all patients were righthanded. The exclusion criteria were: mild, moderate or severe dementia under the Clinical Dementia Rating Scale [14] (scores 1 up), as well as a history of acute cerebrovascular accidents; traumatic brain injury; severe cardiac, metabolic (type 2 diabetes mellitus) pathology; renal failure, uncompensated dysfunction of the thyroid gland; MRI contraindications.

The patients did a number of tests before being split into two groups. Psychometric examination implied a Luria test [15] modified for patients with this kind of vascular pathology; the registered outcome was the sum of words remembered by the patients after 5 repetitions (sets of 10 words). The immediate reproduction of the words in the context of this test allowed dividing the patients into two equal groups with the memorized words indicator lower and higher than the median: $27.7 \pm 1.4$ and $35.8 \pm 0.8$, respectively. The difference in the immediate words reproduction capability was highly significant between the formed groups $(p=0.000006)$. Agewise, the groups were not statistically different from each other $(p=0.26)$, therefore, they were called the compromised WM group and the satisfactory WM group. The groups also showed different results in the delayed words reproduction part of the test $(p=0.0008)$.

The fluency test (FT) [16] results yielded no differences between the groups (summed fluency; $p=0.57$ ).

The correction test results revealed no differences between the groups, too $(p=0.77)$; the test was based on the $n$-back test (Kirchner, 1958), which describes attention stability and concentration capacity [16]

All participants had their cognitive function assessed using the Montreal Cognitive Assessment (MoCa), a cognitive impairment screening tool. This test also returned no differences between the groups $(p=0.68)$; the average values for both groups were $25.6 \pm 1.2$ and $25.0 \pm 0.9$, meaning that cognitive impairments in the patients participating in the study were fairly mild (norm - 26-30 points) [17].

According to the results of the sequential counting test (subtracting sevens from hundred down [15]), the patients were not significantly different.

The rest $\mathrm{fMRI}$ the participants underwent followed the BOLD method, sequence T2*; we used the Magnetom Verio MRI system (Siemens; Germany), 3T. The participants were instructed to fully relax, lie calmly with eyes closed (to exclude stimulation of the visual analyzer) and not think about anything specific. We used the SPM12 (Functional Imaging Laboratory at University College London; UK) application in the MATLAB (MathWorks; USA) environment to process the MRI data. As for the connectivity study, our software of choice was the CONN-18b application (McGovern Institute for Brain Research, Massachusetts Institute of Technology; USA) in the SPM12 toolbox [18]. We assessed connectivity in various neural networks of the brain, including the default mode network (DMN).

We compared connectivity between the two groups defined earlier according to the WM specifics; CONN-18b software (McGovern Institute for Brain Research, Massachusetts Institute of Technology; USA) allowed assessing the significance 
of differences using the standardized regression coefficient adjusted for multiple comparisons.

The same CONN 18b application enabled volumetric studies that yielded general assessments of the gray and white matter volume and that of the cerebrospinal fluid (CSF). The CSF volume was the same in both groups $(p=0.58)$, which signals of the approximately equal level of atrophy in all the participants. We analyzed the gray to white matter ratio.

We used the Statistica-12 package (Dell; USA) for ANOVA and other variance analyses; connectivity assessment was done with the help of SPM-12 and CONN-18b applications in the MATLAB platform. The assessments of connectivity proper and group differences in connectivity were adjusted for multiple comparisons while accounting for the false discovery rate (FDR).

\section{RESULTS}

In the compromised WM group of CICD patients, the connectivity of the left frontal parahippocampal area was limited mainly by the subcortical structures (Fig. 1A). In the satisfactory WM group, we registered negative connectivity between left frontal parahippocampal area and right supramarginal gyrus in addition to the subcortex links, which probably signal of the inhibitory nature of these links (Fig. 1B). The intergroup comparison of connectivity revealed significant differences in the quality of the link between left frontal parahippocampal area and right supramarginal gyrus (Fig. 1B).

Significant intergroup differences in connectivity were also observed between the right cerebellar hemisphere (segments 4 and 5) and the neocortex. There were no negative contingency registered between the cortex and the right cerebellar hemisphere in the compromised WM group (Fig. 2). The differences between the groups were significant $(p<0.05)$ (Fig. 2C).

The cingulate gyrus (part of DMN) correlation links were also different in the compared groups (Fig. 3). Satisfactory WM group exhibited higher connectivity between the right cingulate gyrus and the left lingual gyrus than the compromised WM group (Fig. 3C).

The table below shows statistical indicators of all the intergroup differences discovered that are significant with the multiple comparisons factored in.

Since CICD typically translates into damage to white matter, it is possible that the deterioration of connectivity and memory is associated with the decreasing volume of white matter. We have registered significant differences in gray to white matter ratio between the satisfactory and compromised WM groups. The latter has it significantly higher than the former $(p=0.007)$ (Fig. 4). This fact signals of a relatively large loss of white matter in patients with compromised memory.

\section{DISCUSSION}

CICD patients suffer from progressive memory impairment that mainly affects reproduction of the memorized material [6]. At the early stages of cognitive decline, some CICD patients exhibit WM of the same level as healthy individuals, but it naturally deteriorates with time [19]. In this work, we attempted to study the pathogenetic mechanisms behind deterioration of the verbal operative memory in CICD patients, specifically those related to the changes in functional connectivity of the brain's neural networks. Memory impairment is usually associated with the damage to hippocampus and entorhinal cortex. We registered no significant differences in hippocampus connectivity between satisfactory WM and compromised WM groups; however, such differences were found in the parahippocampal area, where neocortex connects with allocortex. This area receives cognitive and sensory information from the association cortex and passes it to the hippocampus for transition to the long-term memory. Supramarginal gyrus participates in the working memory functions: it helps integrate auditory and visual information. Therefore, the higher connectivity of the parahippocampal area and the supramarginal gyrus registered in the satisfactory WM group were to be expected [19].

Cognitive decline is also associated with the cerebellum. The satisfactory WM group exhibited a significant negative connectivity between cerebellum's right hemisphere (segments 4 and 5), cortex and subcortex. CICD-conditioned operative memory deterioration results from the significant diminution of connectivity between cortex and cerebellum while maintaining connectivity at the subcortex level. The cerebellum is associated mainly with various motor functions. However, in the second half of the past century researchers started to point to the non-motor functions, including cognitive, that the cerebellum partakes in. Interestingly, motor impairments in CICD patients often go in parallel with the cognitive function deterioration. Primarily, the functions in question are those governing speech, learning and memory $[20,21]$. In the cerebellum, these functions employ spatially separated areas; the memory is associated with segments of 4,5 , and 6 [22]. There is a growing body of data revealing involvement of the cerebellum in regulation of sensorimotor, vestibular and cognitive functions [23]. In our studies, WM was also associated with the 4th and 5th segments of the cerebellum. Investigation of the cerebellum's functional topography revealed connections between its frontal part, sensorimotor functions and, what is more, cognitive functions, as well as a number of neural networks, including DMN, frontoparietal networks, etc. It is likely that the neocortexcerebellum discord evidenced by the deteriorating connectivity

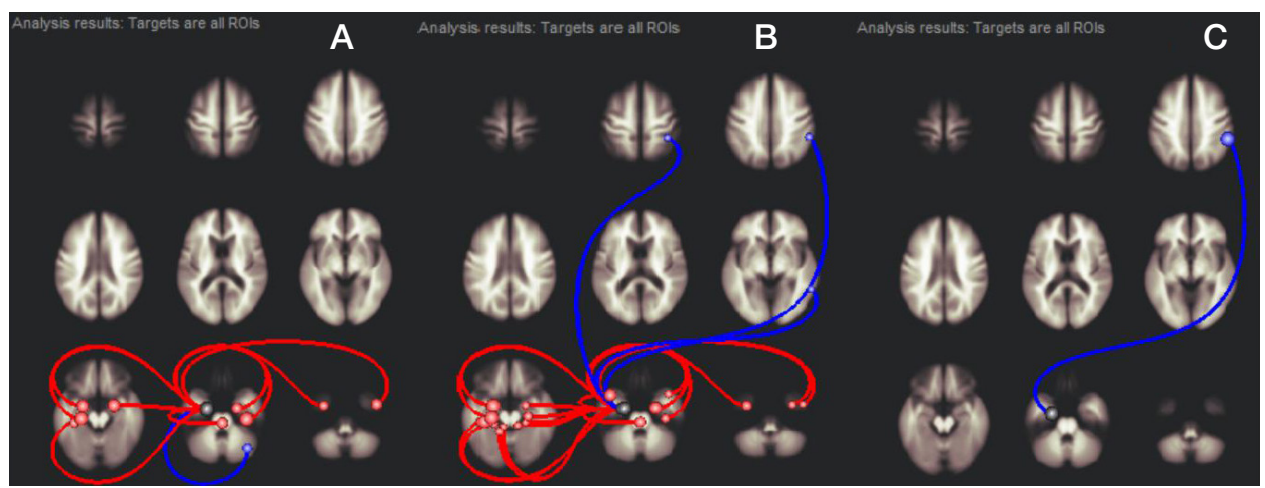

Fig. 1. Left frontal parahippocampal area connectivity to various brain structures; compromised WM group (A) and satisfactory WM group (B). C. Intergroup connectivity comparison (B-A). Red lines show positive correlation; blue lines show negative correlation. Blue lines in the Figure $\mathbf{B}$ indicate significant differences in patients with satisfactory WM compared to patients with compromised WM. Only statistically significant relationships are given, FDR-adjusted for multiple comparisons ( $p$ < 0.05) 
against the background of a developing CICD also contributes to the motor and cognitive function impairments.

DMN also plays a significant role in the memory processes [24]. The lingual gyrus aides visual information processing; it is significantly better connected to the DMN in individuals with satisfactory level of WM.

It can be assumed that the decreasing volume of white matter, which is peculiar to normal aging and aging conditioned by a vascular disease, is one of the reasons behind connectivity and memory deterioration. CICD development translates into damage to the white matter, and it often leads to violations of the gray to white matter ratio, which integratively reflects the predominant loss of gray or white matter. As the diffusion tensor tomography examinations undertaken in the context of longitudinal studies show, maturation of neural connections and development of the fine structure of white matter contribute to growth of the working memory volume $[12,25]$. The loss of the white matter volume peculiar to Alzheimer's and KreutzfeldtJacob neurodegenerative diseases directly correlates with the working memory deflation $[26,27]$. Almost every case of CICD has concomitant arterial hypertension. The blood pressure spikes registered in the elder people complaining about memory deterioration occurred against the background of degenerative changes of not only gray but also white matter, the changes closely resembling those peculiar to the early stages of the Alzheimer's [28]. Overall, white matter lesions (leukoaraiosis) in the presence of CICD correlates with the cognitive decline [29]. It is clear that the decrease in the volume of white matter is directly proportional to the loss of long-axon neurons, including those that participate in the interaction of neocortex, subcortex, and cerebellum, as well as cortex-to-cortex integration.

Thus, it seems likely that the operative memory deterioration in CICD patients is largely associated with the loss of the white matter.

\section{CONCLUSIONS}

1. WM impairments in CICD patients are more significant with the decreasing functional connectivity in the brain neural networks, as registered with fMRI. 2. Significant differences

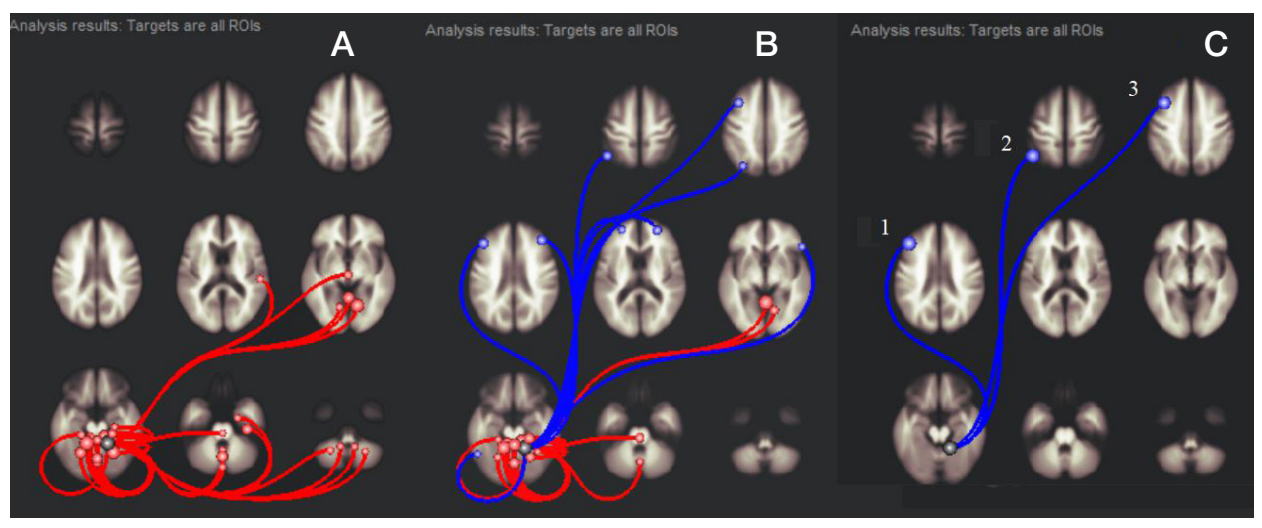

Fig. 2. Connectivity of segments 4 and 5 of the right cerebellum hemisphere to the various brain structures, compromised WM group and satisfactory WM group. Segments $4-5$ belong to the frontal cerebellum. A. Compromised WM group. B. Satisfactory WM group. C. Difference in connectivity (B-A). 1, $2-$ areas of interest are in the left frontoparietal network (FPN); 3 - middle frontal gyrus

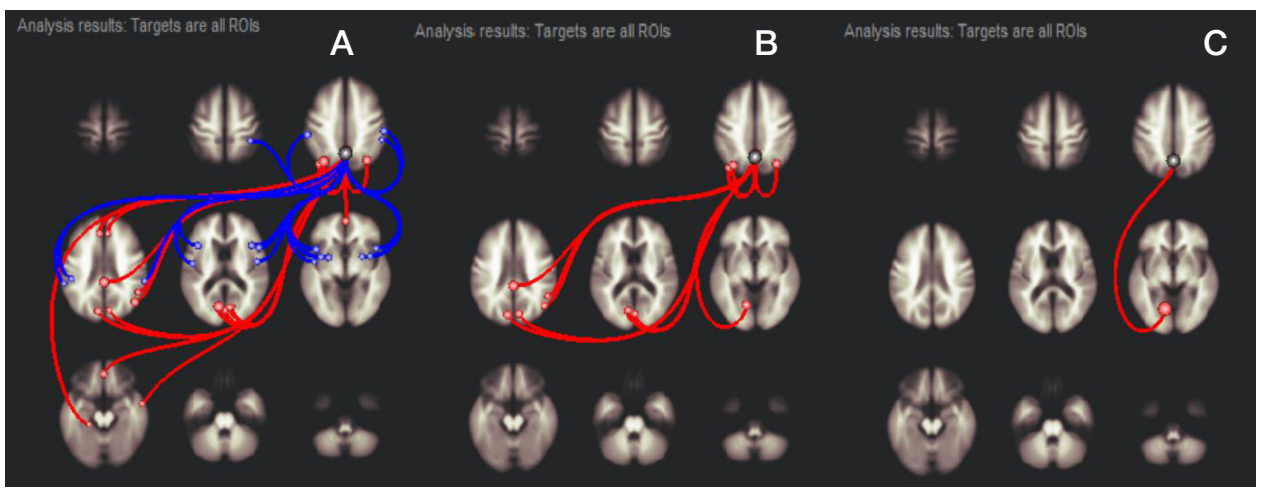

Fig. 3. Connectivity of the right cingulate gyrus posterior (part of DMN), compromised WM group and satisfactory WM group. (See Figures 1 and 2 for designations.) Intergroup differences in connectivity found between the right cingulate gyrus and the left lingual gyrus

Table. Statistical indicators of intergroup differences, satisfactory WM group and compromised WM group

\begin{tabular}{|c|c|c|c|c|}
\hline Areas of interest & Beta & T-test & $\begin{array}{c}\text { Unadjusted } \\
\text { significance level }\end{array}$ & FDR-adjusted $p$-value \\
\hline L-FPN, frontal region - cerebellum & -0.18 & -4.46 & 0.000242 & 0.02196 \\
\hline L-FPN, parietal region - cerebellum & -0.23 & -4.41 & 0.000268 & 0.02196 \\
\hline MFG - cerebellum & -0.21 & -4.05 & 0.000622 & 0.03401 \\
\hline L-PHA - R-SMG & -0.30 & -5.33 & 0.000032 & 0.00524 \\
\hline DMN - L-LG & 0.25 & 4.43 & 0.000259 & 0.04240 \\
\hline
\end{tabular}

Note: beta — standardized regression coefficient; FDR — false discovery rate; negative beta and T-test mean negative connectivity; $L$ — left; $R$ — right; FPN — frontoparietal network; MFG — middle frontal gyrus; PHA — parahippocampal area; SMG — supramarginal gyrus; DMN — default mode network; LG — lingual gyrus. 


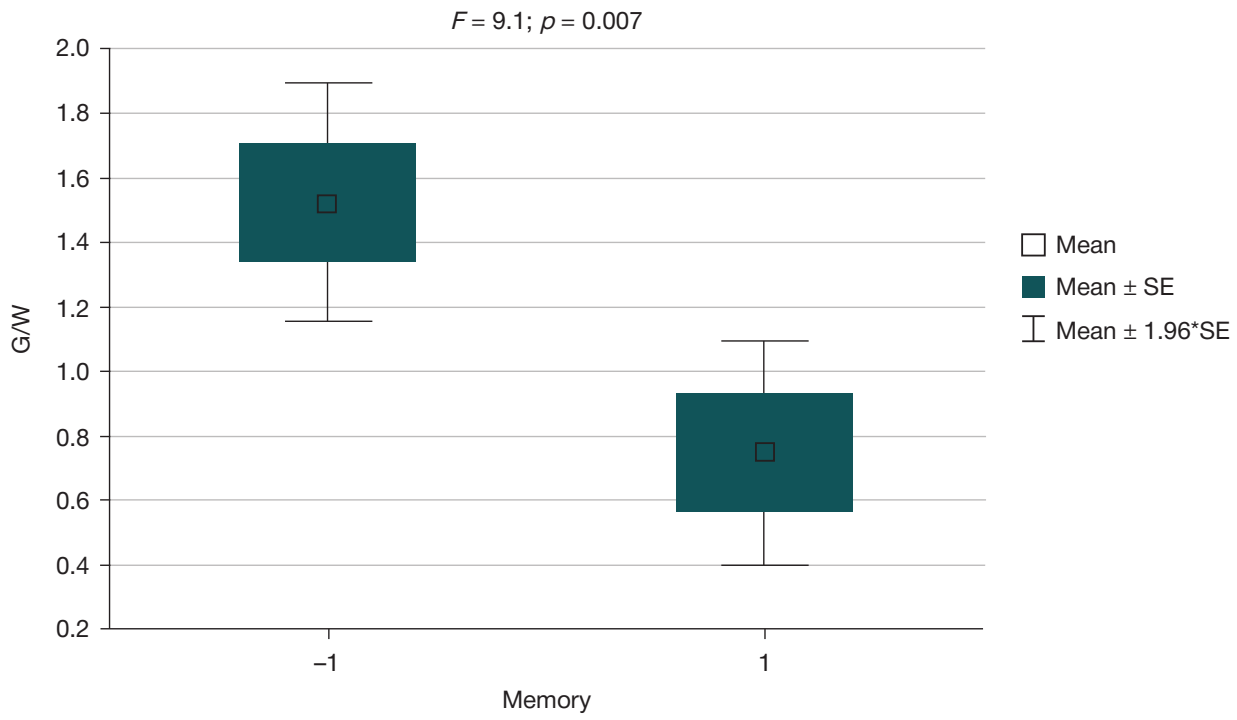

Fig. 4. WM and the relationship between the volume of gray and white matter (G/W). "-1" and "1" — compromised and satisfactory WM groups of CICD patients, respectively. Gray (G) to white (W) matter volume ratio (Y-axis). Statistical indicators of differences between groups: $F$ — Fisher's test, $p$ - level of significance (above)

in the intra-brain connectivity were registered in both the satisfactory WM group and the compromised WM group. The brain parts where those differences were found are right cerebellar hemisphere and left parietal, as well as left frontal areas; left parahippocampal area and right supramarginal gyrus; right cingulate and left lingual gyri. 3. There are significant differences between gray to white matter ratios in patients with satisfactory and compromised memory; memory deterioration is concomitant with the greater loss of white matter. 4. Connectivity alteration reflects pathophysiological mechanisms of the WM disorders that mainly depend on the loss of white matter. Further research would allow evaluating prognostic significance of the revealed decrease in the WM-related connectivity in CICD patients.

\section{References}

1. Levin OS. Discirkuljatornaja jencefalopatija: sovremennye predstavlenija o mehanizmah razvitija i lechenii. Consilium medicum. 2007; (8): 72-9.

2. Yahno NN, Zaharov W, Lokshina AB, Koberskaya NN, Mhitaryan EA. Demencii: rukovodstvo dlja vrachej. M.: MEDpress-inform, 2013; 264 s.

3. Jahno NN. Kognitivnye narushenija $v$ nevrologicheskoj praktike. Nevrologicheskij zhurnal. 2006; 11 (1): 4-12.

4. Tanashyan MM, Medvedev RB, Evdokimenko AN, Gemdzhyan EG, Ckrylev SI, Lagoda OV, i dr. Prognozirovanie ishemicheskih povrezhdenij golovnogo mozga pri rekonstruktivnyh operacijah na vnutrennih sonnyh arterijah. Angiologija i sosudistaja hirurgija. 2017; 23 (1): 59-65.

5. Levin OS, Anikina MA, Vasenina EE. Kognitivnye i nejropsihiatricheskie rasstrojstva pri jekstrapiramidnyh zabolevanijah. Nevrologija, nejropsihiatrija, psihosomatika. 2012; 4 (2S): 22-30.

6. Zaharov V. Lokshina AB. Kognitivnye narushenija pri discirkuljatornoj jencefalopatii. RMZh. 2009; (20): 1325-31.

7. Bennett IJ, Madden DJ. Disconnected Aging: Cerebral White Matter Integrity and Age-Related Differences in Cognition Neuroscience. 2014; r. 187-205. Published online 2013 Nov 23. DOI: 10.1016/j.neuroscience.2013.11.026.

8. van Kesteren MTR, Fernández G, Norris DG, Hermans EJ. Persistent schema-dependent hippocampal-neocortical connectivity during memory encoding and postencoding rest in humans. PNAS. 2010; 107 (16): 7550-5; Available from: https://doi. org/10.1073/pnas.0914892107.

9. Piradov MA, Suponeva NA, Seliverstov YuA, i dr. Vozmozhnosti sovremennyh metodov nejrovizualizacii $v$ izuchenii spontanno aktivnosti golovnogo mozga v sostojanii pokoja. Nevrologicheskij zhurnal. 2016; 21 (1): 4-12. DOI: 10.18821/1560-9545-2016-211-4-12.

10. Ponomareva NV, Fokin VF, Rogaev El, Illarioshkin SN. Vlijanie geneticheskih faktorov na nejrofiziologicheskie mehanizmy nejrodegenerativnyh zabolevanij. Annaly klinicheskoj i jeksperimental'noj nevrologii. 2018: 12 (special'nyj vypusk): 4654. DOI: 10.25692/ACEN.2018.5.6.

11. Andreone BJ, Lacoste B, Gu Ch. Neuronal and vascular interactions. Annu Rev Neurosci. 2015; (38): 25-46. DOI: 10.1146/annurev-neuro-071714-033835.

12. de Leeuw FE, de Groot JC, Oudkerk M, Witteman JC, Hofman A, et al. Hypertension and cerebral white matter lesions in a prospective cohort study. Brain. 2002; 125 (4): 765-72.

13. Tanashjan MM, Maksimova MYu, Domashenko MA Discirkuljatornaja jencefalopatija. Putevoditel' vrachebnyh naznachenij. Terapevticheskij spravochnik. 2015; (2): 1-25.

14. Hughes CP, Berg L, Danziger WL, Coben LA, Martin RL. A new clinical scale for the staging of dementia. Br J Psychiatry. 1982; (140): 566-72.

15. Luriya AR, Simernickaya YeG. O funkcional'nom vzaimodejstvii polusharij golovnogo mozga $\vee$ organizacii verbal'no-mnesticheskih funkcij. Fiziologija cheloveka. 1975; 1 (3): 411-7.

16. Fokin VF, Shabalina AA, Ponomareva NV, Medvedev RB, Lagoda OV, Tanashyan MM. Soprjazhennost' pokazatelej jenergeticheskogo obmena i urovnja gormona stressa kortizola s kognitivnymi harakteristikami bol'nyh discirkuljatornoj jencefalopatiej. Annaly klinicheskoj i jeksperimental'noj nevrologii. 2018; 4 (12): 47-51.

17. Kasten $M$, Bruggemann $N$, Schmidt $A$, Klein Ch. Validity of the MoCA and MMSE in the detection of $\mathrm{MCl}$ and dementia in Parkinson disease. Neurology. 2010; 75 (5): 478-9. DOI:10.1212/ WNL.0b013e3181e7948a.

18. Whitfield-Gabrieli S, Nieto-Castanon A. Conn: A Functional Connectivity Toolbox for Correlated and Anticorrelated Brain Networks. Brain Connect. 2012; 2 (3): 125-41. DOI: 10.1089/ brain.2012.0073

19. Eichenbaum H, Lipton PA. Towards a Functional Organization of the Medial Temporal Lobe Memory System: Role of the Parahippocampal and Medial Entorhinal Cortical Areas. Hippocampus. 2008; (1) 8: 1314-24. 
20. Desmond JE, Fiez JA. Neuroimaging studies of the cerebellum: language, learning and memory. Trend in Cognivity Sciences 1998; 2 (9): 355-61.

21. Larsell $\mathrm{O}$, Jansen J. The human cerebellum, cerebellar connections, and cerebellar cortex. Univerity of Minnesota Press, 1972; $201 \mathrm{p}$.

22. Habas Ch, Kamdar N, Nguyen D, Prater R, Beckmann ChF, et al. Distinct cerebellar contributions to intrinsic connectivity networks. The Journal of Neuroscience. 2009; 29 (26): 8586-94.

23. Schmahmann JD, The cerebellum and cognition. Neuroscience Letters. 2018; Available from: https://DOI.org/10.1016/j. neulet.2018.07.005.

24. Beason-Held LL, Hohman TJ, Venkatraman VAJ, Resnick SM. Brain Network Changes and Memory Decline in Aging. Brain Imaging Behav. 2017; 11 (3): 859-73. DOI: 10.1007/s11682-0169560-3.

25. Krogsrud SK, Fjell AM, Tamnes ChK. Development of white matter microstructure in relation to verbal and visuospatial

\section{Литература}

1. Левин О. С. Дисциркуляторная энцесалопатия: современные представления о механизмах развития и лечении. Consilium medicum. 2007; (8): 72-9.

2. Яхно Н. Н., Захаров В. В., Локшина А. Б., Коберская Н. Н., Мхитарян Э. А. Деменции: руководство для врачей. М. МЕДпресс-информ, 2013; 264 с.

3. Яхно Н. Н. Когнитивные нарушения в неврологической практике. Неврологический журнал. 2006; 11 (1): 4-12.

4. Танашян М. М., Медведев Р. Б., Евдокименко А. Н., Гемджян Э. Г., Скрылев С. И., Лагода О. В. и др. Прогнозирование ишемических повреждений головного мозга при реконструктивных операциях на внутренних сонных артериях Ангиология и сосудистая хирургия. 2017; 23 (1): 59-65.

5. Левин О. С., Аникина М. А., Васенина Е. Е. Когнитивные и нейропсихиатрические расстройства при экстрапирамидных заболеваниях. Неврология, нейропсихиатрия, психосоматика. 2012; 4 (2S): 22-30.

6. Захаров В. В. Локшина А. Б. Когнитивные нарушения при дисциркуляторной энцефалопатии. РМЖ. 2009; (20): 1325-31.

7. Bennett IJ, Madden DJ. Disconnected Aging: Cerebral White Matter Integrity and Age-Related Differences in Cognition. Neuroscience. 2014; p. 187-205. Published online 2013 Nov 23 DOI: 10.1016/j.neuroscience.2013.11.026.

8. van Kesteren MTR, Fernández G, Norris DG, Hermans EJ. Persistent schema-dependent hippocampal-neocortical connectivity during memory encoding and postencoding rest in humans. PNAS. 2010; 107 (16): 7550-5; Available from: https://doi. org/10.1073/pnas.0914892107.

9. Пирадов М. А., Супонева Н. А., Селиверстов Ю. А. и др. Возможности современных методов нейровизуализации в изучении спонтанной активности головного мозга в состоянии покоя. Неврологический журнал. 2016; 21 (1): 4-12. DOI: 10.18821/1560-9545-2016-21-1-4-12.

10. Пономарева Н. В., Фокин В. Ф., Рогаев Е. И., Иллариошкин С. Н. Влияние генетических факторов на нейрофизиологические механизмы нейродегенеративных заболеваний. Анналь клинической и экспериментальной неврологии. 2018: 12 (специальный выпуск): 46-54. DOI: 10.25692/ACEN.2018.5.6.

11. Andreone BJ, Lacoste B, Gu Ch. Neuronal and vascular interactions. Annu Rev Neurosci. 2015; (38): 25-46. DOl: 10.1146/annurev-neuro-071714-033835.

12. de Leeuw FE, de Groot JC, Oudkerk M, Witteman JC, Hofman A, et al. Hypertension and cerebral white matter lesions in a prospective cohort study. Brain. 2002; 125 (4): 765-72.

13. Танашян М. М., Максимова М. Ю., Домашенко М. А Дисциркуляторная энцефалопатия. Путеводитель врачебных назначений. Терапевтический справочник. 2015; (2): 1-25.

14. Hughes CP, Berg L, Danziger WL, Coben LA, Martin RL. A new clinical scale for the staging of dementia. $\mathrm{Br} J$ Psychiatry. 1982; working memory - A longitudinal study. PLoS One. 2018; 13 (4): e0195540. Published online 2018. DOl: 10.1371/journal. pone.0195540.

26. Caverzasi E, Mandelli ML, DeArmond SJ, et al. White matter involvement in sporadic Creutzfeldt-Jakob disease. Brain. 2014; 137 (12): 3339-54. Published online 2014 Nov 3. DOI: 10.1093/ brain/awu298

27. Caballero MAA, Suárez-Calvet $M$, Duering $M$. White matter diffusion alterations precede symptom onset in autosomal dominant Alzheimer's disease. Brain. 2018; 141 (10): 3065-80. Published online 2018. DOI: 10.1093/brain/awy229.

28. Chetouani A, Chawki MB, Hossu G. Cross-sectional variations of white and grey matter in older hypertensive patients with subjective memory complaints. Neuroimage Clin. 2018; (17): 804-10. Published online 2017. DOl:10.1016/j.nicl.2017.12.024.

29. Levin OS. Patologija belogo veshhestva pri discirkuljatornoj jencefalopatii: diagnosticheskie i terapevticheskie aspekty. Trudnyj pacient. 2011; (12): 16-24

(140): 566-72.

15. Лурия А. Р., Симерницкая Э. Г. О функциональном взаимодействии полушарий головного мозга в организации вербально-мнестических функций. Физиология человека. 1975; 1 (3): 411-7.

16. Фокин В. Ф., Шабалина А. А., Пономарева Н. В., Медведев Р. Б. Лагода О. В., Танашян М. М. Сопряженность показателей энергетического обмена и уровня гормона стресса кортизола с когнитивными характеристиками больных дисциркуляторной энцефалопатией. Анналы клинической и экспериментальной неврологии. 2018; 4 (12): 47-51.

17. Kasten M, Bruggemann N, Schmidt A, Klein Ch. Validity of the MoCA and MMSE in the detection of $\mathrm{MCl}$ and dementia in Parkinson disease. Neurology. 2010; 75 (5): 478-9. DOI:10.1212/ WNL.0b013e3181e7948a.

18. Whitfield-Gabrieli S, Nieto-Castanon A. Conn: A Functional Connectivity Toolbox for Correlated and Anticorrelated Brain Networks. Brain Connect. 2012; 2 (3): 125-41. DOI: 10.1089/ brain.2012.0073.

19. Eichenbaum $\mathrm{H}$, Lipton PA. Towards a Functional Organization of the Medial Temporal Lobe Memory System: Role of the Parahippocampal and Medial Entorhinal Cortical Areas. Hippocampus. 2008; (1) 8: 1314-24.

20. Desmond JE, Fiez JA. Neuroimaging studies of the cerebellum: language, learning and memory. Trend in Cognivity Sciences 1998; 2 (9): 355-61.

21. Larsell $\mathrm{O}$, Jansen J. The human cerebellum, cerebellar connections, and cerebellar cortex. Univerity of Minnesota Press, 1972; 201 p.

22. Habas Ch, Kamdar N, Nguyen D, Prater R, Beckmann ChF, et al Distinct cerebellar contributions to intrinsic connectivity networks. The Journal of Neuroscience. 2009; 29 (26): 8586-94.

23. Schmahmann JD, The cerebellum and cognition. Neuroscience Letters. 2018; Available from: https://DOI.org/10.1016/j. neulet.2018.07.005

24. Beason-Held LL, Hohman TJ, Venkatraman VAJ, Resnick SM. Brain Network Changes and Memory Decline in Aging. Brain Imaging Behav. 2017; 11 (3): 859-73. DOI: 10.1007/s11682-0169560-3.

25. Krogsrud SK, Fjell AM, Tamnes ChK. Development of white matter microstructure in relation to verbal and visuospatial working memory - A longitudinal study. PLoS One. 2018; 13 (4): e0195540. Published online 2018. DOI: 10.1371/journal. pone.0195540.

26. Caverzasi E, Mandelli ML, DeArmond SJ, et al. White matter involvement in sporadic Creutzfeldt-Jakob disease. Brain. 2014; 137 (12): 3339-54. Published online 2014 Nov 3. DOI: 10.1093/ brain/awu298.

27. Caballero MAA, Suárez-Calvet $M$, Duering $M$. White matter 


\section{ORIGINAL RESEARCH I NEUROLOGY}

diffusion alterations precede symptom onset in autosomal dominant Alzheimer's disease. Brain. 2018; 141 (10): 3065-80. Published online 2018. DOI: 10.1093/brain/awy229.

28. Chetouani A, Chawki MB, Hossu G. Cross-sectional variations of white and grey matter in older hypertensive patients with subjective memory complaints. Neuroimage Clin. 2018; (17): 804-10. Published online 2017. DOl:10.1016/j.nicl.2017.12.024. 29. Левин О. С. Патология белого вещества при дисциркуляторной энцефалопатии: диагностические и терапевтические аспекты. Трудный пациент. 2011; (12): 16-24. 